110 Magma

\title{
Poemas de Acauam Oliveira E José VIRGíNIO
}

Suave matéria prima de um cotidiano cronicamente inviável

Um processo de criação colaborativo-experimental

(seleção de excertos)

\section{Elisa}

p/ Murilo Rubião

Quando estamos juntos

sua presença me constrange e aborrece

e nenhum dos dois é capaz

de fazer nenhum bem.

um ao lado do outro

prostrados ímpares

Quando separados

não paro de desejar sua presença

mesmo antevendo os eternos

momentos de tédio e aborrecimento

já sentindo o arrependimento

ainda mais profundo

por ser anterior ao próprio ato.

Preso entre o ser e seu oposto

não adianta lutar ou resistir.

Eu preciso da ausência de Elisa. 


\section{Paradoxo}

Quem foi o corno

que fodeu minha mulher?

\section{No Metrô}

Uma velha sentada

Duas moças em pé ao lado (lindas)

conversando

Só o olho pra velha.

$\mathrm{O}$ que ela tem a oferecer

(oferece existindo)

me toca mais no fundo. 


\section{Descaminhos}

Um bulevar, uma passante cachos cachos

bagos túrgidos pendendo

o andar altruísta perfila cabeças

e coleciona momentos

não existe nada mais no mundo

o susto premeditado

escreve porque é com as palavras

abordagem!

esta estufa de flores simples

arde num incêndio

mas resfria-se em clichês

umas barracas alguns camelôs

alguns camelos

o andar altruísta de quem tudo dá

entre escombros esquecidos

caminhos perdidos de paralelepípedos

encurralava-se no beco sem palavras

não sei se

isso ou aquilo

um grito

um choro mudo

um sino

ela de cachos em lastros

será violentada

(pelo vulto dum monstro)

ele de bagos túrgidos

mas mesmo assim é possível

que da imensa dor

nasça uma flor no futuro

como rima ou ramo internos

de um ventre prematuro

- e aí, ela aborta ou tem o filho? 